\title{
Compliance of Islamic Financial Institutions in Pakistan with the Principles of Islamic Commercial Law: An Illusion or Reality (Views of Islamic Law Scholars)
}

\author{
Ali Sajjad ${ }^{1 *}$, Lutfullah Saqib ${ }^{2}$, Muhammad Zia-ul-Haq ${ }^{3}$ \\ ${ }^{1}$ Management Science Department, Superior University, Lahore, Pakistan \\ ${ }^{2}$ University of Swat, Swat, Pakistan \\ ${ }^{3}$ Islamic Research Institute (IRI), International Islamic University, Islamabad, Pakistan
}

\section{Keywords}

Sharī'ah Board

Sharī'ah Compliance

Islamic Banking Institutions

Islamic Commercial Law

Received: 11 September 2019

Accepted: 23 April 2020

\begin{abstract}
Sharī'ah compliance of Islamic financial institutions is one of the most important aspects of research in these days. In Pakistan, Sharī'ah compliance is made essential for Islamic Banking Institutions (IBIs) by the regulatory body, the State Bank of Pakistan (SBP). To comply with the Sharī'ah's rules and regulations, SBP, therefore, introduced a comprehensive Sharī'ah Governance Framework (SGF) in 2015. It is the duty of Sharīah board to ensure that transactions of the IBIs fall under the ambit of Islamic commercial law. This study, primarily, discusses two dimensions regarding the compliance of the IBIs' business, i.e., whether it is an illusion or reality. Discussion in "Focused Group", an important technique of qualitative research method has been adopted. While following this, data has been collected through one-on-one interviews. A sample size of fourteen (14) Informants (7 Shar'̄'ah advisors associated with Islamic banks and finance institutions, and 7 Sharī'ah scholars) was drawn; covering, mainly, two major cities of Pakistan i.e., Lahore and Karachi. Moreover, Sharī'ah Advisors have been selected from the Securities and Exchange Commission of Pakistan (SECP) registered list. Sharī'ah scholars, on the other hand, have been taken from recognized educational institutes of HEC. Interview questions, of the present work, are directly related to Shari' ah compliance of IBIs in Pakistan.The findings reveal that Islamic banks are Shar'̄'ah compliant in Pakistan.
\end{abstract}

KAUJIE Classification: B0, S5

JEL Classification: G21, G30, Z12 


\section{INTRODUCTION}

Islamic banking and finance are emerging as an alternative to conventional interest-based banking and financing (Samad, Gardner, \& Cook, 2005). The basic objective of Islamic finance is to lead to redistribution of wealth for improving the financial health of the needy in line with the requirements of Shari' ${ }^{-} a h$. The teachings of Islam, of course, are comprehensive in nature; covering all aspects of life. Moreover, there are clear instructions even for aspects like haläl and haräm. It emphasises universal faith, promoting brotherhood, social equality, and fairness in economic activities for the welfare of the mankind. Moreover, Islamic commercial law provides comprehensive guidelines for sustainable economic growth. Islamic banks and other financial institutions contribute to economic growth by performing different activities as per precepts of Islamic law. One important feature of IFIs is to share the risk among different investors as per these rules. These institutions focus on freedom and fairness; as universal principles as per the instructions of Allah almighty (Abbasi et al., 2012; Ahmad, Malik, \& Humayoun, 2010; Ahmad, Ur Rehman, \& Saif, 2010). A strong and well-functioning Islamic financial system paves a way for regional financial integration worldwide. It also contributes to the uplifting economy, social development and in creating job opportunities (El Qorchi, 2005).

Sharī'ah compliance, while having the above discussion in mind, plays a crucial role in IFI governance. It's mandatory for all IFIs, as per the SBP's guidelines, to ensure that their activities and operations are Sharī'ah based or at least Shari' 'ah compliant- under any stretch of explanation. The regulatory body in this respect comprises the Sharī'ah advisors of financial institutions. In view of Hamza (2013) members of Sharī'ah board are remunerated and appointed by Islamic banks. They just play the role of advisory, and do not have the necessary authority to make the decision.

To undertake Islamic banking operations, Sharī'ah boards are appointed represented by at least 3 Sharī'ah scholars. State Bank of Pakistan (SBP) has introduced the criteria for such Shari'ah scholars. This criterion is, apart from the usual aspects of honesty and integrity, based on a person's qualifications both in terms of experience and qualification in understanding Islamic banking and finance transactions. These Sharí ${ }^{\top}$ ah scholars are chosen by the banks, approved by the SBP and appointed by the banks to oversee their Islamic banking operations. They, therefore, serve as SBP's eyes at the operational level of Islamic banking operations in the country. Their independence and neutrality are, of course, indispensable for Sharī ${ }^{-}$ah compliance of Islamic banks and other Islamic financial institutions (Akhtar, 2006).

As per Islamic Banking Bulletin, assets of the Islamic banking industry, while recording quarterly growth of $4.9 \%$, increased by Rs. 132 billion to reach Rs. 2,790 billion by the end of March 2019. The market share of Islamic banking as on that date constituted a share of $15 \%$ in assets and $15.6 \%$ in deposits of the overall banking industry in the country State bank of Pakistan (2019).

Although we might be discussing the Islamic financial institutions in general, but for this study, we are focusing on Islamic banking institutions (IBIs) operating in Pakistan. Respondents' view expressed for this study is also about the IBIs in general. The IFIs are 
operating in many countries and have been offering substantial Sharī'ah-compliant products and services in the last thirty years (Gait \& Worthington, 2008). Islamic finance is practiced, predominantly, in the Muslim world throughout the middle ages. Later on, European iňAznanciers and businessmen adopted different modes, techniques, and instruments of Islamic finance-keeping in view the beneficial nature of such banking. Moreover, Islamic finance can contribute to economic growth and development. Financial intermediation motivates individuals and business entities to save, as well as, offering them a range of instruments to fulfill their financial needs by sharing risk and reward (Mohieldin, Iqbal, Rostom, \& Fu, 2012). Besides, Islamic financial institutions are the first to come up with the idea of interest-free transactions. In Malaysia, for instance, a pilgrimage fund was established in the late 1950s; accumulating the savings of those people intending to make the pilgrimage to Makah.

As Johan, Dali, Suki, and Hafit (2017) mentioned that Islamic banks are in "between a hammer and the anvil" situation as they are facing challenges of producing competitive products. While having the importance of Islamic finance law in mind, the main objective of this study is to investigate whether the Islamic banks and other Islamic financial institutions in Pakistan are Shari'ah compliant or not. This study, in other words, explores whether Sharī'ah compliance in IBIs is reality or illusion.

\section{LITERATURE REVIEW}

There are many reasons to introduce Islamic banking for Muslim customers. The main, among these is that conventional banking follows an interest-based system while interest is strictly prohibited by Sharī'ah ${ }^{1}$. Muslims, therefore, need such institutions, as alternatives to conventional banking, that provide an opportunity to carry out transactions as per the precepts of Shari' 'ah . There are some issues with the IBIs. For instance, it is felt that customers do not have exact knowledge about IBIs' operations or the return on their investment (Alam, Arslan, Saleem, Raziq, \& Aleem, 2011; Gait \& Worthington, 2007).

Hunjra, Akhtar, Akbar, and Niazi (2011) affirmed that customers felt barriers to the adoption of the Islamic banking system for getting services. In addition, the IBIs have a small network branch system, inconvenient location of branches. Furthermore, Sharī'ah principles are not implemented properly (Akram, Rafique, \& Alam, 2011).

To comply with Sharī'ah rules and to uphold customers' satisfaction, IFIs have to constitute a Sharī'ah board (SB). It works independently for monitoring the activities of Islamic

\footnotetext{
${ }^{1}$ Sharī'ah strictly prohibits interest based loans. There are many verses of the Holy Qur'ān and Hadīth of the Holy Prophet (SAW) that confirms this prohibition. For instance, in the Holy Qur'ān Allah, the exalted, says "O Ye Who Believe! Fear Allah, and give up what remains of your demand for usury, if ye are indeed believers. If ye do it not, take notice of war from Allah and His apostle. But if ye turn back ye shall have your capital sums: deal not unjustly and ye shall not be dealt unjustly" (Qur'ān 2:278-279). In another verse the Lord of Universe says "That they took rib $\bar{a}$ (usury), though they were forbidden and that they devoured men's substance wrongfully. We have prepared for those among men who reject faith a grievous punishment" (Qur'ān 4:161). From Jābir, may Allah be pleased with him, said: "The messenger of Allah (SAW) has cursed one who charges riba , he who gives it, one who records it, and the two witnesses; and he said, "They are equal" (Muslim Sahih, Chapter on ribā, Hadìth no. 1598).
} 
financial institutions in the light of Islamic commercial law. The SB's duty is to monitor and regulate the ongoing activities of the IBIs in accordance with the Islamic commercial laws in line with regulations introduced by the SBP time to time.

This study works on two perspectives of the IBIs in Pakistan in terms of Shar' 'ah compliance i.e., it's a reality or an illusion. Reality is the quality or state of being actual or true (Zemach, 1992). Moreover, in physical terms, it is the totality of a system, known and unknown (Saridakis, 2016). Illusion, according to Bach and Poloschek (2006) is something that deceives or misleads intellectually or perception of something objectively existing in such a way as to cause misinterpretation of its actual nature.

\section{Compliance of IBIs with the Principles of Islamic Commercial Law: A Reality}

Aim of Islamic financial institutions, as mentioned earlier, is to provide Sharī'ah compliant alternative to conventional banking. These IFIs, or more specifically the IBIs are working according to Sharí' ${ }^{-} a h^{\prime}$ s principles; contributing to the economy in different ways. Many customers think that Shari' 'ah compliance of IBIs is a reality as these institutions are offering pure Shari 'ah based transactions. In addition, these institutions need to work in removing the inequalities and improving the general standard of living. This aspect (Sharī'ah based) of IBIs has been discussed by many scholars in their scholastic works. The following lines would clarify it further.

In view of Kaleem and Ahmed (2010), Islamic microfinance institutions are socially and financially sustainable and based on the concepts of volunteer services among community members, and brotherhood. Charity based Islamic microfinance provides money for production and consumption to the needy and thus, targets social and economic social needs of the poorest segments of the society. Furthermore, it can help to reduce indebtedness and the unequal distribution of wealth in society (Ahmed, 2006). Moreover, the Islamic financial institutions strictly follow Shari 'ah compliant features, principally, the prohibition of taking or giving interest. In these institutions, the actual profit is distributed after the completion of actual business transaction and no profit is given in the form of any predefined amount. Likewise, IBIs are restricted from lending money to customers that contradict Sharī'ah principles (Amin \& Isa, 2008b). Farook, Kabir Hassan, and Lanis (2011) posit that customers are more satisfied with Islamic banking compared to conventional banking. It shows that Islamic Banking is purely based on Sharī'ah's principles; whereas conventional banking is entirely based on profit maximization through interest-based borrowing and lending. Moreover, operations of IFIs are arguably better than conventional banking, though conventional banking has an advantage in terms of technical efficiency (Shahid, Rehman, Niazi, \& Raoof, 2010). Additionally, Islamic banking has emerged as a strong financial system; based on financing, assets, profitability, effectiveness, etc.; while maintaining consistent growth (Awan, 2009). Akram et al. (2011) examined the development and growth phases as well as prospects of Islamic banking in Pakistan. It showed that Islamic banking paved with the rapid market share of banking services.

Shari' 'ah advisors ensure compliance with rules and regulations of all the products and services; enforcing policies, procedures, and agreements as per principles of Islamic com- 
mercial law. They also prepare a report on the bank's annual financial statements in respect of its Sharī'ah compliance. They review compliance while having access to all accounts, documents, and records. Moreover, they also view operations of the institution periodically, along with the coordination of employees who are responsible for Shari' 'ah compliance State Bank of Pakistan (2008).

\section{METHODOLOGY}

Descriptive research, as a matter of fact is taken from words and pictures rather than numbers. It, of course contains quotations said by the participants to illustrate and present the findings. Descriptive data include; field notes, photographs, transcripts, audios recordings, and documents (Bogdan \& Biklen, 1997). It is simply used to describe the various aspects of the phenomenon in minute detail. Moreover, it supports to uncover new facts and meanings through observation, description, and documents (Graneheim \& Lundman, 2004). In addition, a descriptive type of research uses three methods of data collection; including questionnaires, interviews (open-ended), and observations. This is done, usually, through focused group techniques. In the present work the same research technique of qualitative research has been followed. Interviews have been conducted with fourteen (14) informants (7 Sharī'ah advisors associated with banks and 7 Shari 'ah scholars); exploring whether the IBIs in Pakistan are Sharī'ah compliant, in their perception or not (Smith, Flowers, \& Larkin, 2009).

These scholars are primarily related to two major cities of Pakistan i.e., Karachi and Lahore. Shari'‘ah advisors, on one hand, are selected from the SECP's (Securities and Exchange Commission of Pakistan) registered advisor's list (also associated with Islamic banks) and Sharī'ah scholars on the other hand are selected from recognized educational institutes of HEC. In addition, interview questions are related to the "reality" and "illusion" aspects of Shari'‘ah compliance of IFIs in Pakistan.

Data analysis is established through an inductive approach, guided by the available literature. Convenience and purposive sampling techniques are used too, which is appropriate for the selection of a relevant and most useful sample from a population (Marshall, 1996). Moreover, interview sessions are held through telephonic sources-as this is the easiest way for the collection of data. Furthermore, semi-structured interviews have been carried out, recorded in audio, and subsequently transcribed. The data obtained from the interviews are thematically analyzed at the later stage; a method of analyzing, identifying, and recording the data from participants (Steely et al., 2006).

\section{RESULTS AND DISCUSSION}

Demographics of Sharī'ah advisor i.e., their length of service, gender, age, and registration numbers presented in detail. 
TABLE 1

Demographics Sharī‘ah Advisors (SA) SECP Register List 2017

\begin{tabular}{lcccll}
\hline \hline S. No & Informants & Length of Service & Gender & Age & Registration No. \\
\hline 1 & Informants (SA.1) & 8 & $\mathrm{M}$ & 38 & SECP/IFD/A1 \\
2 & Informants (SA.2) & 6 & $\mathrm{M}$ & 35 & SECP/IFD/A2 \\
3 & Informants (SA.3) & 11 & $\mathrm{M}$ & 37 & SECP/IFD/A3 \\
4 & Informants (SA.4) & 10 & $\mathrm{M}$ & 34 & SECP/IFD/A4 \\
5 & Informants (SA.5) & 10 & $\mathrm{M}$ & 36 & SECP/IFD/A5 \\
6 & Informants (SA.6) & 9 & $\mathrm{M}$ & 37 & SECP/IFD/A6 \\
7 & Informants (SA.7) & 6 & $\mathrm{M}$ & 34 & SECP/IFD/A7 \\
\hline \hline
\end{tabular}

TABLE 2

Shows themes by Participants

\begin{tabular}{lclc}
\hline \hline Informant (SA.1) & Emerging Themes & Informant (SA.2) & Emerging Themes \\
\hline Maximization of Profit & 4 & Maximization of Profit & 2 \\
Sustainable Development & 3 & Sustainable Development & 3 \\
Supervision & 5 & Supervision & 2 \\
Product and Services Quality & 4 & Product and Services Quality & 2 \\
Working Environment & 4 & Working Environment & 1 \\
\hline Total & 20 & Total & Emerging Themes \\
\hline Informant (SA.3) & Emerging Themes & Informant (SA.4) & 3 \\
\hline Maximization of Profit & 3 & Maximization of Profit & 3 \\
Sustainable Development & 3 & Sustainable Development & 1 \\
Supervision & 3 & Supervision & 2 \\
Product and Services Quality & 2 & Product and Services Quality & 2 \\
Working Environment & 2 & Working Environment & 11 \\
\hline Total & 13 & Total & 2 \\
\hline Informant (SA.5) & Emerging Themes & Informant (SA.6) & 1 \\
\hline Maximization of Profit & 3 & Maximization of Profit & 2 \\
Sustainable Development & 2 & Sustainable Development & 1 \\
Supervision & 2 & Supervision & 2 \\
Product and Services Quality & 2 & Product and Services Quality & 08 \\
Working Environment & 1 & Working environment & \\
\hline Total & 10 & Total & \\
\hline Informant (SA.7) & 2 & & \\
Maximization of Profit & Emerging Themes & & \\
Sustainable Development & 2 & & \\
Supervision & 2 & & \\
Product and Services Quality & 2 & & \\
Working Environment & 2 & & \\
Total & & & \\
\hline \hline
\end{tabular}

All seven informant's (Sharī'ah advisors) interviews have been analyzed with the two basic objectives. Firstly, during analysis, all-important themes are mentioned with the utmost care for the purpose not to miss any important theme derived from the interview. At this 
phase, extracted emerging themes, related to prescribed themes, were carefully analyzed. There are total 20 emerging themes, in total. One from Sharī'ah advisor No.1, 10 from Sharī'ah advisor No.2, 13 from Sharī'ah advisor No.3, 11 from Sharī'ah advisor No.4, 10 from Sharī'ah advisor No.5, 08 from Sharī'ah advisor No.6 and 09 from Sharī'ah advisor No.7 respectively. The detailed list of total emerging themes of all informants (Shari' 'ah advisors) is given in Table 2 .

\section{Maximization of Profit}

As per Askari, Iqbal, and Mirakhor (2011), Islamic banks use the interest-free system, risksharing techniques, and profit maximization for their investors. The response received from Sharī'ah advisors, regarding the same fact can be elaborated as under.

"Being a Sharī'ah Advisor, in my point of view earning of IFIs is really based on principles of Sharīah " (SA.1)

"yes, Islamic bank offers interest-free profit". (SA.7)

"In my view, I always care about investors' interest". (SA.1)

"In my view, IFIs keep an eye on investor's interests to build up their trust". (SA.2)

"I follow Shari'ah rules and regulations in their procedure as per guidelines provided by the State Bank of Pakistan".( SA.3)

"I try my best for the interest-free earning; based on profit and loss mechanism policy". (SA.4)

"Definitely, IBIs operate in the best interest of investors and they are managing their transactions as per rules of Islamic commercial law". (SA.5)

"Yes, IBIs are presenting their best efforts to promote Islamic banking and finance according to the principles of Islamic commercial law". (SA.6)

\section{Sustainable Development}

In view of Furqani and Mulyany (2009), Islamic banks and financial institutions play an effective role as financial intermediaries; facilitating growth, savings, and sustainable development. The following details may clarify Sharı'‘ah advisor's opinion regarding the same characteristics.

"In my opinion, as a Sharī'ah Advisor, Islamic banks are actively involved in sustainable development as per guidelines of Islamic finance laws". (SA.1)

"We have real economic activities as per principles of Islamic commercial law. These economic activities, predominantly, include sustainable development". (SA.2)

"During my service as a Sharī'ah Advisor, I have noticed that Islamic banks and other Islamic financial institutions are actively involved in sustainable development-though the process is a little bit slow". (SA.3)

"I think Islamic banks and financial institutions target sustainable development as a major factor in their policies." (SA.4)

"Of course, Islamic banks care about sustainable development in their commercial activities".(SA.5)

"Yes, to some extent". (SA.7) 
"Yes, Islamic bank offers transactions having sustainable development as a major part". (SA.7)

\section{Social Welfare}

Hassan and Latiff (2009) contend that IFIs contribute to society's development in the shape of corporate social responsibility. Islamic banks in Pakistan play the same role. The following point may reveal it as contended by the Sharī'ah advisors selected for the sample.

"Absolutely, we focus on corporate social responsibilities through charitable activities". (SA.1)

"Yes, we actively participate and extend our hands to help the needy and poor persons". (SA.2)

"Practically speaking, we can say that Islamic banks are involved (though to some extent) in social development. In some Islamic banks, some separate accounts are opened for the same purpose". (SA.3)

"Yes, in my opinion, Islamic banks are actively involved in various activities related to social development". (SA.4)

"Yes, Islamic banks fulfill the obligation of social development to some extent". (SA.7)

\section{Supervision}

Abbasi et al. (2012) contend that the IBIs are directed and controlled by a legitimate regulatory body, known as the Sharī'ah Board or the Sharī'ah Supervisory Board (SSB). The purpose of the SSB is to ensure that the bank operates in conformity with the principles of Shari' 'ah. The viewpoint of SSB, regarding the supervision of commercial transactions is as under.

"Yes, Islamic banks' transactions are closely watched". (SA.1)

"My role, as Sharī'ah Advisor, is independent in nature. I supervise all sort of commercial activities operated at my bank". (SA.2)

"Yes, Shanī'ah Advisors watch all types of commercial transactions carried on by their banks". (SA3)

"Yes, Sharī'ah advisors are independent to supervise each transaction of their corresponding financial institution". (SA.5)

"To some extent, Islamic banks' Sharī'ah advisors supervise the commercial activities of their corresponding banks". (SA.6)

\section{Product and Services Quality}

Khan, Ahmed, and Nawaz (2011) investigated the relationship among products and service quality, customer satisfaction, and performance of Islamic banks. All these aspects, if based on Shari' ${ }^{-} a h$, can play a vital role in the development of Islamic banks. The following details would show whether service quality, customer satisfaction, and performance of Islamic banks are Sharī'ah based or not. 
"I experienced that the IBIs provide products and services as per principles of Shar1'ah ". (SA.1)

"Practically speaking, products and services of Islamic banks are purely Sharī'ah based; as all the products have been approved by the Shari'ah advisors". (SA.2)

"Being a Sharī'ah advisor I can say firmly that all products and services of Islamic banks are purely based on Sharī'ah ". (SA.3)

"Of course, all commercial products of Islamic banks are based on the principles of Islamic commercial law". (SA.4)

"As per my experience, with 98\% accuracy, you can say IFI's products and services are purely Sharī'ah board". (SA.5)

\section{Working Environment}

Kalid and Jailani (2019) highlighted that lacking of good values among staffs in any organizational always lead to malicious cases such as contract dispute, bribery fraud, of documents, bad debts, cheating or scam, bankruptcy and others.

"Yes, Islamic banks provide an Islamic working environment that promotes cooperation, equity, unity, and spirituality at the workplace." (SA.1)

"Practically speaking, Islamic banks provide a good working environment as per principles of Islamic ethics". (SA.2)

"Yes, as a Sharī'ah advisor I have noticed that Islamic banks offer an environment where equality is always the order of the day". (SA3)

"Being a Shari'ah advisor, I have observed that Islamic financial institutions care extensively about the development of Islamic working environment". (SA.4)

"Yes, Islamic banks provide equal opportunities to all in their products, services, employment, etc.". (SA.5).

This tabular \& graphical representation aims to describe the most frequent collective themes of all seven informants who are Shari' 'ah advisors of Islamic banks. These are the words or statements which Sharī'ah advisors have made during face-to-face interviews. This study contains two different directions for Shar'̄'ah compliance of IFIs i.e., illusion and reality. Majority of Sharī'ah advisors emphasize on the maximization of profit with the value of 10. Likewise, sustainable development, social welfare, supervision shows the 8 values respectively; meaning thereby that banks' Sharī'ah scholars are in support of reality regarding Shari 'ah compliance of the IBIs. Some Shari' 'ah advisors consider it illusion as the value of maximization of profit is just 1 , sustainable development 2 , social welfare 3 , and supervision 5. For products/services and working environment, the majority of the Shari' ah advisors suggested reality because its values are 12 for both. On the other side, it shows only 2 values for product and services quality and 3 values for the working environment. Based on the results, it can be said that the majority of the Shari'ah advisors are in favor of reality regarding Sharī'ah compliance in IFIs. 
TABLE 3

Phenomenological Reduction: Sharī‘ah Advisors taken from SECP Register List 2017

\begin{tabular}{|c|c|c|c|}
\hline Categories & Themes & Reality & Illusion \\
\hline \multirow[t]{4}{*}{ Maximization of Profit } & 1. Real profit & 10 & 1 \\
\hline & 2. Profit and loss sharing ratios & & \\
\hline & 3. Interest-free profit & & \\
\hline & 4. Wealth maximization & & \\
\hline \multirow[t]{5}{*}{ Sustainable Developments } & 1. Government support & 8 & 2 \\
\hline & 2. Economic activities & & \\
\hline & 3. Growth & & \\
\hline & 4. Renowned projects & & \\
\hline & 5. Investor wealth maximization & & \\
\hline \multirow[t]{5}{*}{ Social Welfare } & 1. Equal distribution of wealth & 8 & 3 \\
\hline & 2. CSR & & \\
\hline & 3. Poor and needy & & \\
\hline & 4. Charity & & \\
\hline & 5. Zakat & & \\
\hline \multirow[t]{4}{*}{ Supervision } & 1. SBP Regulatory system & 8 & 5 \\
\hline & 2. Neutral Sharī'ah Board System & & \\
\hline & 3. Sharī'ah Governance & & \\
\hline & 4. Sharī'ah involvement & & \\
\hline \multirow[t]{3}{*}{ Product and Services Quality } & 1. Alternative to conventional banking & 12 & 2 \\
\hline & 2. Modern technology & & \\
\hline & 3. Fairly launched products and services & & \\
\hline \multirow[t]{5}{*}{ Working Environment } & 1. Good environment & 12 & 3 \\
\hline & 2. Cooperative & & \\
\hline & 3. Protected environment & & \\
\hline & 4. Association & & \\
\hline & 5. Customer care & & \\
\hline
\end{tabular}

Authors' focused coding for Phenomenological reduction

TABLE 4

Tabular Representation of Reality by Informant's (SA) Collective Frequencies

\begin{tabular}{ll}
\hline \hline Themes & Reality (N) \\
\hline Maximization of profit & 10 \\
Sustainable development & 8 \\
Social welfare & 8 \\
Supervision & 8 \\
Product and services quality & 12 \\
Working environment & 12 \\
\hline \hline
\end{tabular}




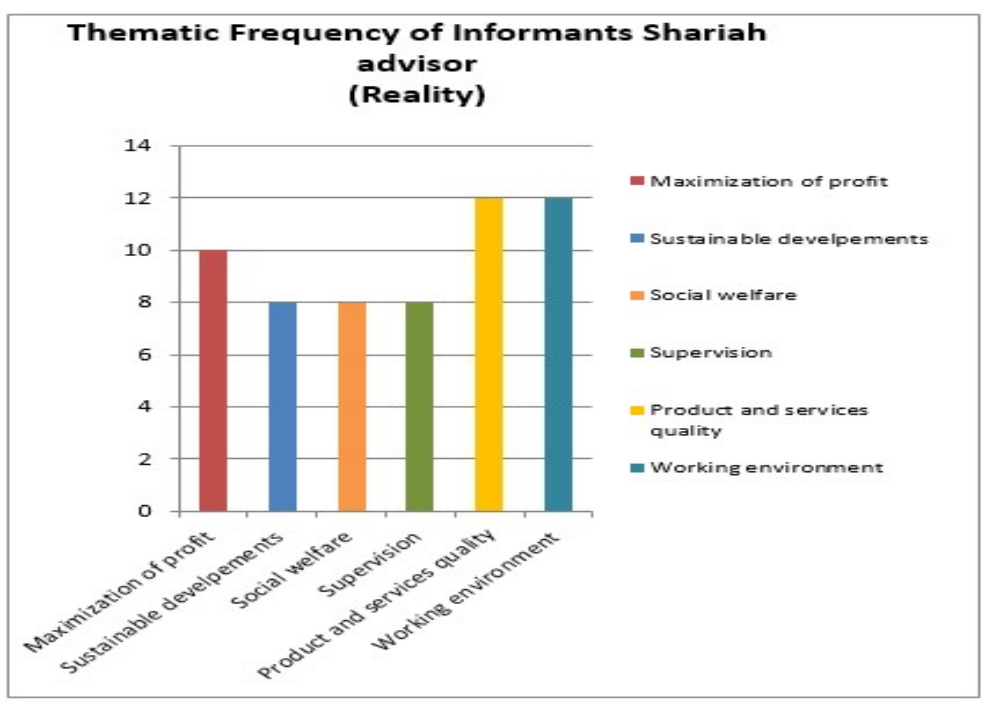

FIGURE 1. Authors self-created on the basis of informant's (Sharī'ah Advisors) view on reality

TABLE 5

Tabular Representation on Illusion by Informant's (SA) Collective Frequencies

\begin{tabular}{ll}
\hline \hline Themes & Reality (N) \\
\hline Maximization of profit & 1 \\
Sustainable development & 2 \\
Social welfare & 3 \\
Supervision & 5 \\
Product and services quality & 2 \\
Working environment & 3 \\
\hline \hline
\end{tabular}

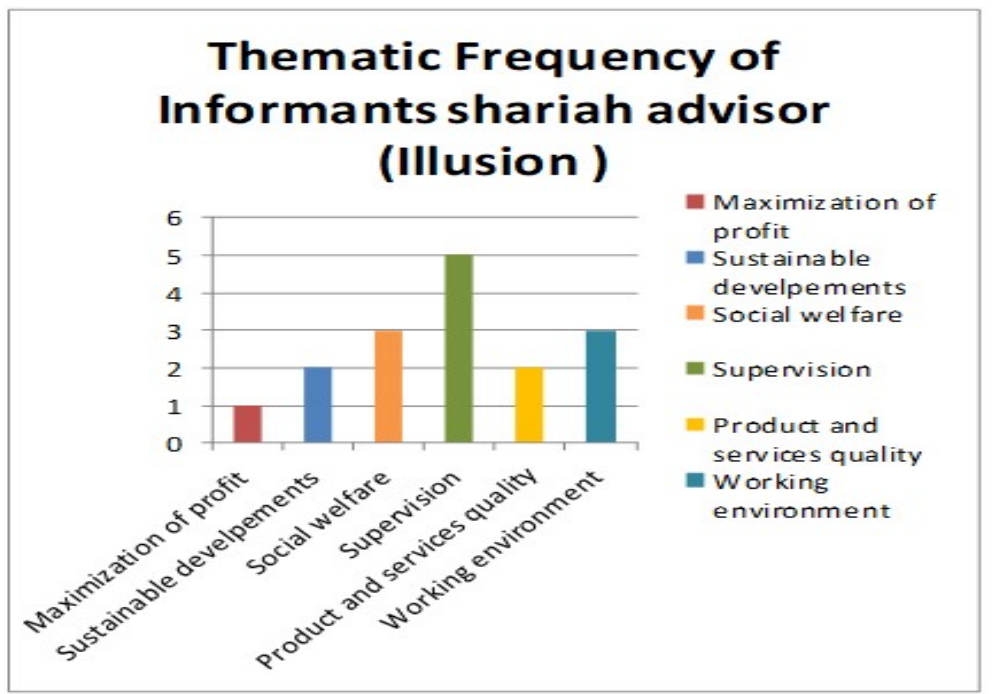

FIGURE 2. Shows authors self-created on the basis of informant's (Sharī'ah Advisors) view 
TABLE 6

Demographics Sharī'ah Scholar (SS) Sharī'ah compliance of Islamic financial institutions in Pakistan:

Illusion or reality Sharī'ah scholars' view

\begin{tabular}{cccccc}
\hline \hline Sr. No. & Informants & Length of Service & Gender & Age & HEC Recog. Inst. \\
\hline 1 & Informants (SS.1) & 5 & $\mathrm{M}$ & 32 & $\mathrm{~A} 1$ \\
2 & Informants (SS.2) & 4 & $\mathrm{M}$ & 31 & $\mathrm{~A} 2$ \\
3 & Informants (SS.3) & 9 & $\mathrm{M}$ & 36 & $\mathrm{~A} 3$ \\
4 & Informants (SS.4) & 10 & $\mathrm{M}$ & 40 & $\mathrm{~A} 4$ \\
5 & Informants (SS.5) & 11 & $\mathrm{M}$ & 42 & $\mathrm{~A} 5$ \\
6 & Informants (SS.6) & 9 & $\mathrm{M}$ & 38 & $\mathrm{~A} 6$ \\
7 & Informants (SS.7) & 5 & $\mathrm{~F}$ & 33 & $\mathrm{~A} 7$ \\
\hline
\end{tabular}

All seven informants' (Sharī'ah scholars) interviews are profoundly studied. During the analysis, various themes have been developed from the informants' opinions. The following table may clarify the process (of theming) with minute details.

TABLE 7

Shows themes by Participants

\begin{tabular}{lclc}
\hline \hline Informant (SA.1) & Emerging Themes & Informant (SA.2) & Emerging Themes \\
\hline Maximization of Profit & 2 & Maximization of Profit & 4 \\
Sustainable Development & 3 & Sustainable Development & 3 \\
Supervision & 2 & Supervision & 3 \\
Product and Services Quality & 2 & Product and Services Quality & 3 \\
Working Environment & 2 & Working Environment & 3 \\
\hline Total & 11 & Total & 11 \\
\hline Informant (SA.3) & Emerging Themes & Informant (SA.4) & Emerging Themes \\
\hline Maximization of Profit & 3 & Maximization of Profit & 2 \\
Sustainable Development & 4 & Sustainable Development & 1 \\
Supervision & 1 & Supervision & 1 \\
Product and Services Quality & 0 & Product and Services Quality & 1 \\
Working Environment & 0 & Working Environment & 2 \\
\hline Total & 08 & Total & Emerging Themes \\
\hline Informant (SA.5) & Emerging Themes & Informant (SA.6) & 2 \\
\hline Maximization of Profit & 1 & Maximization of Profit & 1 \\
Sustainable Development & 1 & Sustainable Development & 1 \\
Supervision & 0 & Supervision & 1 \\
Product and Services Quality & 0 & Product and Services Quality & 1 \\
Working Environment & 1 & Working environment & 06 \\
\hline Total & 03 & Total & \\
\hline Informant (SA.7) & Emerging Themes & & \\
\hline Maximization of Profit & 2 & & \\
Sustainable Development & 1 & & \\
Supervision & 1 & & \\
Product and Services Quality & 1 & & \\
Working Environment & 2 & & \\
Total & 07 & & \\
\hline \hline
\end{tabular}




\section{Maximization of Profit}

IFIs generate profit by using Islamic products, such as, provision of funds and acceptance of deposits. By using Islamic modes of financing, IFIs ensure the maximum level of profit (Waemustafa \& Sukri, 2016).

"No, Islamic banks do not earn the real profit rather it earns interest like conventional banks". (SS.1)

"Absolutely, yes our Islamic banks do offer interest-free profit". (SS.2)

"I think that IFIs earn true profit as per rules of Islamic commercial law". (SS.3)

"Profit, earned by the Islamic banks, is according to the principles of Islamic law". (SS.4)

"IFIs institutions provide real profit to their customers". (SS.5)

"Absolutely, yes our Islamic banks provide a true profit-the one supported by the principles of Islamic commercial law". (SS.6)

"I do not think soâAęIslamic banks just change the term 'interest' with 'profit'". (SS.7)

\section{Sustainable Developments}

In the Islamic economic system, investors have to comply with the principles of Shari'a i.e., to do justice with all stakeholders, protect the economic environment and sustain the development process (Al-Roubaie \& Sarea, 2019).

"No, in my view Islamic banks are not rightly involved in sustainable development as per principles of Islamic commercial law". (SS.1)

"Yes, to some extent Islamic banking institutions are involved in sustainable development". (SS.2)

"In my opinion, Islamic banking institutions are supporting social development activities". (SS.3)

"If IFIs work ideally, it can be proved beneficial to our economy and society". (SS.4)

"Yes, our Islamic institutions have a huge role in equal distribution of wealth and sustainable development as per the principles of Islamic law". (SS.5)

"Unfortunately, IFI's currently working as an alternative to conventional structures and, therefore, are not involved in sustainable development as required by Islamic law". (SS.6) "Every economic circle, of course, contributes to the development of a country. IFIs, too, is very special for the same through sukük (commercial certificate) and other projects".(SS.7)

\section{Social Welfare}

Islamic financial institutions work under the umbrella of Shari ${ }^{-}$ah which guides the whole process and social activities. Furthermore, CSR practices need much more attention in Pakistan (Durrani, 2016).

"In my view, Islamic business ethics, corporate social responsibility of the business organizations and Islamic financial institutions should be seen as a benefit rather than a cost. These institutions are really involved in various activities indispensable for the development of society". (SS.1)

"I believe that the collection of zakāt is not done effectively" (SS.1) 
"I believe that IFIs are in the process of lining their activities for the social development as required by Islamic law". (SS.3)

\section{Supervision}

Sharī'ah supervisory board is one of the important parts of Islamic Financial Institutions, appointed by the board of directors to monitor the rules and regulations. Sharī'ah supervisors monitored the issues related to compliance and other activities (Amin \& Isa, 2008a). Furthermore, they supervise the banking activities and ensure that products and services are as per the principles of Islamic commercial law (Rao, 2018).

"In my opinion, Sharī'ah advisors actively supervise all commercial transactions of their corresponding banks". (SS.1)

"No, I do not think so. The powers of Sharī'ah advisors are very limited and, therefore, they do not supervise Islamic banks' activities minutely". (SS.2)

"No, Sharī'ah advisors do not supervise their corresponding banks' activities; owing to the fact of their limited powers and lack of required knowledge, predominantly, that of contemporary accounting and finance". (SS.3)

"In my opinion, Sharī'ah advisers supervise all commercial activities of IFIs-though to a very limited extent". (SS.4)

"As a Sharī'ah scholar, I do not think that Sharī'ah advisors can supervise commercial transactions of their corresponding banks as they are not independent. Independent Shari ${ }^{\star} a h$ advisors, indeed, follow the policies of Sharī'ah in every transaction, whether it is related to the customer or it is related to the investments". (SS.5)

"No, in my opinion, most of the Shari'‘ah advisors do not have the capacity required for active supervision. I think Madrassa (Religious schools) must follow a proper curriculum which is designed by experts for a Shari ${ }^{\circ}$ ah advisor. Moreover, they should be authorized and should be certified by the professional institutions for Shari' ${ }^{6}$ ah advisors. They should understand the basic concepts of the modern economy". (SS.6)

"In my opinion, which may be wrong, Shari'‘ah advisors do not check commercial transactions properly". (SS.7)

\section{Product and Services Quality}

IFIs provide Sharī'ah compliant products and services to protect the Muslims' interest (Ali \& Raza, 2017). Islamic banks are liable to provide Islamic products and services that are in line with Sharīah rules to protect Muslims from interest.

"I do not think so that products and service quality of Islamic banks follow principles of Islamic commercial law". (SS.1)

"No, products and service quality of IFIs are not up to the level required by Islamic law". (SS.2)

"Yes, products and service quality of Islamic banks match the quality required by Islamic law". (SS.3)

"I do not think that Islamic banks provide products and service quality according to Islamic principles". (SS.4) 
"Yes, Islamic banks provide products and service quality as required by Islamic law". (SS.5) "Yes, in my opinion, IFIs follow principles of Islamic law in the provision of products and service quality". (SS.6)

"No," (SS.7)

TABLE 8

Phenomenological Reductions: Sharī‘ah Scholars (SS)

\begin{tabular}{|c|c|c|c|}
\hline Categories & Themes & Reality & Illusion \\
\hline Maximization of Profit & 1. Real profit & 6 & 2 \\
\hline \multirow[t]{3}{*}{ Sustainable Development } & 1. Sustainable growth & 7 & 3 \\
\hline & 2. Mega projects & & \\
\hline & 3. Economy beneficial & & \\
\hline \multirow[t]{4}{*}{ Social Welfare } & 1. Equal distribution of wealth & 4 & 3 \\
\hline & 2. Zakāh & & \\
\hline & 3. Funds & & \\
\hline & 4. CSR & & \\
\hline \multirow[t]{5}{*}{ Supervision } & 1. Independent Sharī'ah advisor & 5 & 4 \\
\hline & 2. Reporting system & & \\
\hline & 3. Regulatory authority & & \\
\hline & 4. Sharī'ah compliance & & \\
\hline & 5. SBP Supervision & & \\
\hline \multirow[t]{4}{*}{ Product and Services Quality } & 1. Fair marketing & 5 & 2 \\
\hline & 2. Awareness & & \\
\hline & 3. Alternative to the commercial banks & & \\
\hline & 4. Modern technology & & \\
\hline \multirow[t]{2}{*}{ Working Environment } & 1. Language & 4 & 2 \\
\hline & 2. Professional behavior & & \\
\hline
\end{tabular}

Author's focused coding for phenomenological reduction

\section{Working Environment}

Chebab and Zribi (2012) examined the main elements behind customers moving from a conventional bank to Islamic banks. They find that the quality of the relationship between the customer and the bank influencing customer choice.

"No, IFIs do not have a working environment proposed by Islamic law. There is always cheating of customers in many respects ..I do not want to go in detail". (SS.1)

"I had a great experience of working with an Islamic bank. Their dealings with the customers are not as required by Islamic finance law. Moreover, their environment is not the one approved by Islamic work ethics. For instance, equal opportunities are not provided to all employees and customers". (SS.2)

"I have experience of working in Islamic banks. Their relationship is fair with the customers and employees. However, there is space for further improvement". (SS.3)

"Alhamdulillah, a good atmosphere is available in Islamic banks but needs improvement, too, in the windows sector". (SS.4) 
"No, IFIs do not provide a good working environment envisaged by Islamic commercial law". (SS.5)

This tabular \& graphical representation aims to describe the collective themes of all seven informants (Sharīah scholar). These are the words or statements which they made during face-to-face interviews. This study contains two different directions for Shari'‘ ah compliance of IFIs i.e., illusion and reality. The majority of Sharī'ah scholars emphasised on the maximization of profit. Its dimension shows 06 in both tabular and graph form; meaning thereby that most of Sharī'ah scholars are in favor of reality. Only one informant (Sharī'ah scholar) considered Sharī'ah compliance as an illusion. Likewise, sustainable development, social welfare, supervision show the 7, 4, 5 values respectively; meaning thereby that Shari' 'ah scholars are in support of reality regarding compliance in IFIs. Some Sharī'ah scholars considered it illusion as the value of sustainable development is 7 , social welfare 4, and supervision 5. For products/services and working environment, the majority of the Sharī'ah scholar opted reality because its values are 5 and 4 . It can be said, after having these figures in hands that majority of the Shari 'ah scholars are in favour of reality regarding Sharī'ah compliance in IFIs.

TABLE 9

Tabular representation on reality by informant's (SS) collective frequencies

\begin{tabular}{ll}
\hline \hline Themes & Reality (N) \\
\hline Maximization of profit & 6 \\
Sustainable development & 7 \\
Social welfare & 4 \\
Supervision & 5 \\
Product and services quality & 5 \\
Working environment & 4 \\
\hline \hline
\end{tabular}

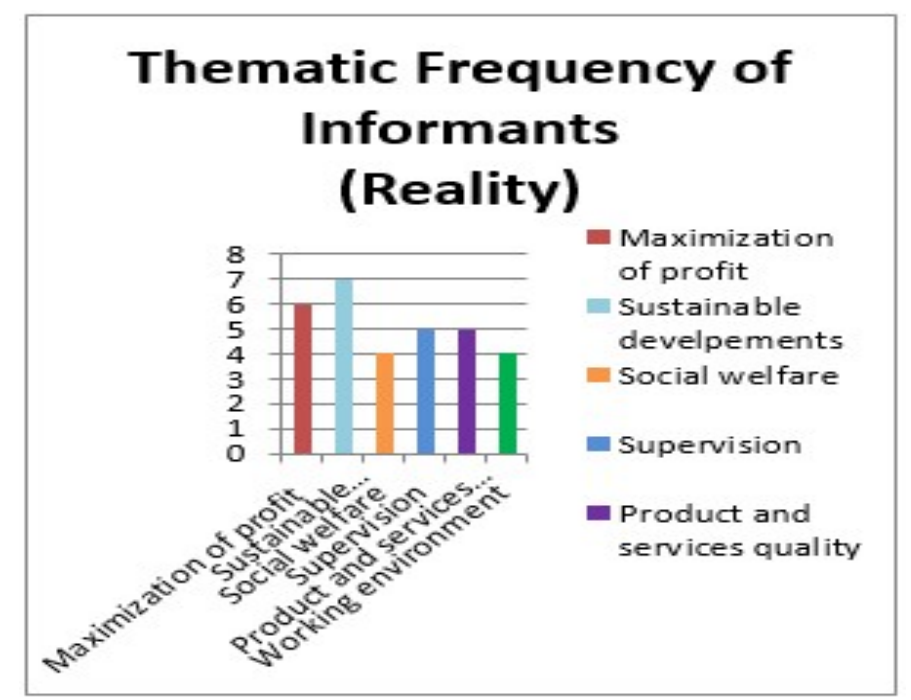

FIGURE 3. Authors self-created on the basis of informant's (Sharī'ah Scholars) view on reality 
TABLE 10

Tabular representation on illusion by informant's (SS) collective frequencies

\begin{tabular}{ll}
\hline \hline Categories & Illusion (N) \\
\hline Maximization of profit & 2 \\
Sustainable development & 3 \\
Social welfare & 3 \\
Supervision & 4 \\
Product and services quality & 2 \\
Working environment & 2 \\
\hline \hline
\end{tabular}

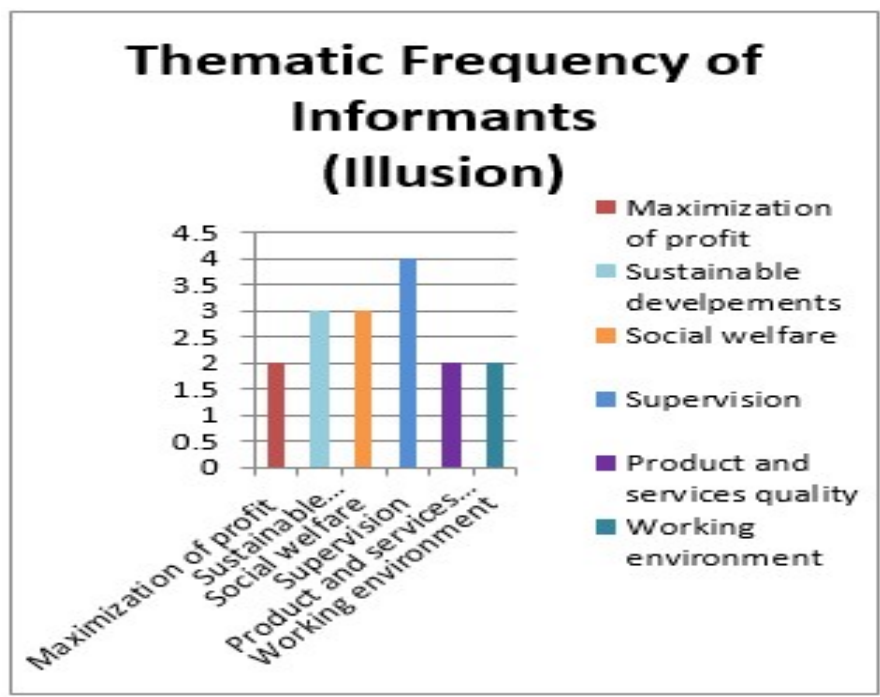

FIGURE 4. Authors self-created on the basis of informant's (Sharī'ah Scholars) view on illusion

\section{CONCLUSION}

The current research based on the views of selected Sharī'ah advisors associated with Islamic banks in Pakistan and some Sharī'ah scholars graduating from HEC, Pakistan's recognized madaris chains not associated with Islamic banks, tested whether the IBIs' compliance to Sharī'ah is a reality or an illusion. Here the term 'reality' means that Islamic banks follow both in letter and spirit, the principles of Islamic commercial law in their business and commercial transactions. The term 'illusion', on the other hand, has a contrary meaning to that of 'reality'.

The Sharī'ah advisors and Sharī'ah scholars were interviewed regarding Sharī'ah compliance of Islamic banks. They were asked various questions-directly and indirectly, related to the commercial activities of IBIs in Pakistan. In addition, they were asked about the working environment offered by the Islamic banks for their customers and employees.

Islamic banks and financial institutions are bound to comply with the rules of Shari' ah . As per the view of the Sharī ah advisors and Sharī'ah scholars included in the study, Islamic 
banks' compliance to Sharī'ah is a reality; as they follow the principles of commercial law to the possible extent. But only some Sharī'ah advisors and Sharī'ah scholars have a contradiction with this opinion by saying that the bank's Sharī'ah compliance is an illusion they are doing business for their own interest and benefits without giving due weightage to the Sharī'ah.

This study might be helpful to the current and potential customers, who have doubts in their minds regarding Sharí'ah compliance. Findings show that IBIs are following the principles of Islamic commercial law in their day to day transactions. The State Bank of Pakistan has taken many initiatives for making the transactions of Islamic banks in line with the rules and regulations of Islamic law. However, still, there is a space for improvement. As a matter of fact, an effective and efficient Shari' 'ah compliance system enhances the confidence level of the customers. Researchers, in the future may like to include other stakeholders of Islamic finance for assessing the perception of the general public and specific groups in the society about Islamic banking and finance. This ultimately would help in evolving Islamic finance system in the long run on sustainable basis.

\section{REFERENCES}

Abbasi, T. H., Kausar, A., Ashiq, H., Inam, H., Nasar, H., \& Amjad, R. (2012). Corporate social responsibility disclosure: A comparison between Islamic and conventional financial institutions in Bahawalpur region. Research Journal of Finance and Accounting, 3(3), 51-62.

Ahmad, A., Malik, M. I., \& Humayoun, A. A. (2010). Banking developments in Pakistan: A journey from conventional to Islamic banking. European Journal of Social Sciences, 17(1), 12-17.

Ahmad, A., Ur Rehman, K., \& Saif, M. I. (2010). Islamic banking experience of Pakistan: Comparison between Islamic and conventional banks. International Journal of Business and Management, 5(2), 137-143. doi: https://doi.org/10.5539/ijbm.v5n2p137

Ahmed, H. (2006). Islamic law, adaptability and financial development. Islamic Economic Studies, 13(2), 79-101.

Akhtar, S. (2006). Pakistan banking sector-the need for second tier of reforms. Address by Dr Shamshad Akhtar, at Pakistan Banking Association, London, UK.

Akram, M., Rafique, M., \& Alam, H. M. (2011). Prospects of Islamic banking: Reflections from Pakistan. Australian Journal of Business and Management Research, 1(2), 125-134.

Al-Roubaie, A., \& Sarea, A. M. (2019). Green investment and sustainable development: The case of Islamic finance. Journal of Islamic Business and Management, 9(1), 14-24. doi: https://doi.org/10.26501/jibm/2019.0901-002

Alam, H. M., Arslan, M., Saleem, M., Raziq, H., \& Aleem, A. (2011). Development of Islamic banking in Pakistan. Interdisciplinary Journal of Contemporary Research In Business, 3(1), 261-276.

Ali, M., \& Raza, S. A. (2017). Service quality perception and customer satisfaction in Islamic banks of Pakistan: the modified SERVQUAL model. Total Quality Management $\mathcal{F}$ Business Excellence, 28(5-6), 559-577. doi: https://doi.org/10.1080/14783363.2015.1100517 
Amin, M., \& Isa, Z. (2008a). An examination of the relationship between service quality perception and customer satisfaction. International Journal of Islamic and Middle Eastern Finance and Management, 1(3), 191-209. doi: https://doi.org/10.1108/17538390810901131 Amin, M., \& Isa, Z. (2008b). An examination of the relationship between service quality perception and customer satisfaction: A SEM approach towards Malaysian Islamic banking. International Journal of Islamic and Middle Eastern Finance and Management, 1(3), 191-209. doi: https://doi.org/10.1108/17538390810901131

Askari, H., Iqbal, Z., \& Mirakhor, A. (2011). New issues in Islamic finance and economics: Progress and challenges (Vol. 753): New York, NY: John Wiley \& Sons. doi: https://doi.org/10.1002/9781119207696

Awan, A. G. (2009). Comparison of Islamic and conventional banking in Pakistan. Paper presented at the COMSATS International Business Research Conference (CBRC): A Conference for Business, Economics and Behavioral Sciences, Lahore, Pakistan.

Bach, M., \& Poloschek, C. M. (2006). Optical illusions. Advances in Clinical Neuroscience $\mathcal{E}$ Rehabilitation, 6(2), 20-21.

Bogdan, R., \& Biklen, S. K. (1997). Qualitative research for education. Boston, MA: Allyn $\&$ Bacon

Chebab, S., \& Zribi, H. (2012). Expected regret and Islamic banking in emerging countries: The case of Tunisia. Journal of Business Studies Quarterly, 3(4), 119.

Durrani, B. (2016). Islamic concept and contemporary corporate social responsibility: Comparative study between Islamic banks and conventional banks in Pakistan. Journal of Managerial Sciences, 10(2), 318-332.

El Qorchi, M. (2005). Islamic finance gears up. Finance and Development, 42(4), 46.

Farook, S., Kabir Hassan, M., Lanis, R. (2011). Determinants of corporate social responsibility disclosure: The case of Islamic banks. Journal of Islamic Accounting and Business Research, 2(2), 114-141. doi: https://doi.org/10.1108/17590811111170539

Furqani, H., \& Mulyany, R. (2009). Islamic banking and economic growth: Empirical evidence from Malaysia. Journal of Economic Cooperation E Development, 30(2), 59-74.

Gait, A., \& Worthington, A. (2008). An empirical survey of individual consumer, business firm and financial institution attitudes towards Islamic methods of finance. International Journal of Social Economics, 35(11), 783-808. doi: https://doi.org/10.1108/03068290810905423

Gait, A. H., \& Worthington, A. C. (2007). A primer on Islamic finance: Definitions, sources, principles and methods (Working Papers Series). School of Accounting \& Finance, University of Wollongong, Wollongong, Australia.

Graneheim, U. H., \& Lundman, B. (2004). Qualitative content analysis in nursing research: Concepts, procedures and measures to achieve trustworthiness. Nurse Education Today, 24(2), 105-112. doi: https://doi.org/10.1016/j.nedt.2003.10.001

Hamza, H. (2013). Sharia governance in Islamic banks: Effectiveness and supervision model. International Journal of Islamic and Middle Eastern Finance and Management, 6(3), 226-237. doi: https://doi.org/10.1108/IMEFM-02-2013-0021 
Hassan, A., \& Latiff, S. B. A. (2009). Corporate social responsibility of Islamic financial institutions and businesses: Optimizing charity value. Humanomics, 25(3), 177-188. doi: https://doi.org/10.1108/08288660910986900

Hunjra, A. I., Akhtar, M. N., Akbar, S. W., \& Niazi, G. S. K. (2011). Relationship between customer satisfaction and service quality of Islamic banks. World Applied Sciences Journal, 13(3), 453-459.

Johan, Z. J., Dali, N., Suki, A. A., \& Hafit, N. I. A. (2017). Customers' intention towards Shar'`ah compliant credit cards: A pilot study. International Journal of Academic Research in Business and Social Sciences, 7(4), 772-779. doi: https://doi.org/10.6007/IJARBSS/v7-i4/2887

Kaleem, A., \& Ahmed, S. (2010). The Qur'ān and poverty alleviation: A theoretical model for charity-based Islamic Microfinance Institutions (MFIs). Nonprofit and Voluntary Sector Quarterly, 39(3), 409-428. doi: https://doi.org/10.1177/0899764009332466

Kalid, S. H., \& Jailani, M. R. M. (2019). Theoretical framework of Islamic work ethics as a medium of $d a$ 'wah in business environment. Journal of Islamic, 4(19), 231-242.

Khan, M. M., Ahmed, I., \& Nawaz, M. M. (2011). Student's perspective of service quality in higher learning institutions; An evidence based approach. International Journal of Business and Social Science, 2(11), 159-164.

Marshall, M. N. (1996). Sampling for qualitative research. Family Practice, 13(6), 522-526. doi: https://doi.org/10.1093/fampra/13.6.522

Mohieldin, M., Iqbal, Z., Rostom, A., \& Fu, X. (2012). The role of Islamic finance in enhancing financial inclusion in Organization of Islamic Cooperation (OIC) countries (Policy Research Working Paper No: 5920). Islamic Economics and Finance Working Group, The World Bank, Washington, D.C. US. doi: https://doi.org/10.1596/1813-94505920

Rao, P. (2018). A Reviev on CAMELS+(S):(S) Sharī'ah rating for Islamic banks. Research Journal of Economics and Business Studies, 7(07), 68-73.

Samad, A., Gardner, N. D., \& Cook, B. J. (2005). Islamic banking and finance in theory and practice: The experience of Malaysia and Bahrain. The American Journal of Islamic Social Sciences, 22(2), 69-86. doi: https://doi.org/10.35632/ajiss.v22i2.458

Saridakis, E. (2016). Information, reality, and modern physics. International Studies in the Philosophy of Science, 30(4), 327-341.

doi: https://doi.org/10.1080/02698595.2017.1331980

Shahid, H., Rehman, R., Niazi, G. K., \& Raoof, A. (2010). Efficiencies comparison of Islamic and conventional banks of Pakistan. International Research Journal of Finance and Economics, 49(9), 24-42.

Smith, J. A., Flowers, P., \& Larkin, M. (2009). Interpretative phenomenological analysis: Theory, method and research. Thousand Oaks, CA: Sage.

Steely, H. T., Dillow, G. W., Bian, L., Grundstad, J., Braun, T. A., Casavant, T. L., . . . Clark, A. F. (2006). Protein expression in a transformed trabecular meshwork cell line: Proteome analysis. Molecular Vision, 12(4), 372-383. 
Waemustafa, W., \& Sukri, S. (2016). Sharī'ah compliance and lawful profit making dilemma in Malaysian Islamic banks. International Journal of Business and Technopreneurship, 3(1), 131-139. doi: https://doi.org/10.2139/ssrn.2824903

State bank of Pakistan. (2008). Instructions for Sharī'ah compliance in Islamic banking institutions. Islamic Banking Department, State Bank of Pakistan. Karachi, Pakistan.

State bank of Pakistan. (2019). Islamic banking bulletin. Islamic Banking Department, State Bank of Pakistan. Karachi, Pakistan.

Zemach, E. M. (1992). The reality of meaning $\mathcal{E}$ the meaning of "reality". Providence, Rhode Island: Brown University Press. 